\title{
POLA PERUBAHAN PENGGUNAAN LAHAN DAN NERACA PANGAN DI KABUPATEN KARAWANG
}

\section{Land Use Change Pattern and the Balance of Food Production in Karawang District}

\author{
Alwan Rafiuddin 1)*, Widiatmaka'), dan Khursatul Munibah²) \\ 1) Alumni Program Studi Ilmu Perencanaan Wilayah, Sekolah Pascasarjana, Institut Pertanian Bogor, Kampus IPB \\ Darmaga, Bogor, 16680 \\ 2) Departemen Ilmu Tanah dan Sumberdaya Lahan, Fakultas Pertanian IPB, Jl. Meranti Kampus IPB Dramaga, \\ Bogor 16680
}

\begin{abstract}
Karawang Regency is one of the rice production center in West Java. However, the dynamics of land use and land cover changes in the region is estimated to be high because of its proximity to the nation's capital. These dynamics have led to changes in rice production. This research was conducted to study the patterns of land use and land cover change over the period of 2000-2013 and its relation to the balance of food production. Changes in land use and land cover were identified by the use of Landsat TM imagery of 2000, 2003, 2007, 2010 and 2013. The production and productivity of rice were obtained from statistical data of Karawang Regency, 2001-2014. The results showed that in the period between 2000 and 2013, paddy fields identified from imagery were decreased from 116,268 ha in 2000 to become 103,866 ha in 2013. The most extensive changes of land use and land cover were the changes from the rice to the settlements. The most dominant area of increased settlement comes from the paddy fields and dry land agriculture. The average decrease of paddy fields during $2000-2013$ was $0.93 \%$ per year. This has resulted in a decrease in the contributions of Karawang to export rice for surrounding regions by $5 \%$ during the last 13 years.
\end{abstract}

Keywords: Balance of food production, paddy fields, pattern of land use change

\begin{abstract}
ABSTRAK
Kabupaten Karawang merupakan salah satu wilayah lumbung padi di Jawa Barat. Dinamika perubahan penggunaan lahan dan tutupan lahan di wilayah ini relatif tinggi karena kedekatannya dengan ibukota negara, menyebabkan adanya dinamika wilayah dalam kemampuan memproduksi beras. Penelitian ini bertujuan untuk menganalisis pola perubahan penggunaan lahan dan tutupan lahan selama periode 2000-2013 dan hubungannya dengan neraca pangan dan produksi beras. Perubahan penggunaan lahan dan tutupan lahan diidentifikasi menggunakan citra Landsat TM tahun liputan 2000, 2003, 2007, 2010 dan 2013. Produksi dan produktivitas padi dianalisis dari data statistik Kabupaten Karawang tahun 2001-2014. Hasil penelitian menunjukkan bahwa pada periode antara tahun 2000 dan 2013, luas lahan sawah turun dari 116,268 ha menjadi 103,866 ha. Perubahan penggunaan lahan dan tutupan lahan terbesar adalah dari sawah menjadi pemukiman. Pemukiman yang terdiri dari lahan terbangun untuk tempat tinggal dan tempat bekerja meningkat dari 11,759 ha pada tahun 2000 menjadi 30,155 ha pada tahun 2013. Penggunaan lahan yang paling dominan berubah adalah lahan sawah dan pertanian lahan kering. Penurunan luas lahan sawah di Kabupaten Karawang selama 2000 - 2013 rata-rata 0.93\% tahun. Penurunan luas lahan sawah ini telah mengakibatkan penurunan kontribusi untuk menyumbang beras keluar wilayah, sebesar $5 \%$ dalam kurun 13 tahun terakhir.
\end{abstract}

Kata kunci: Neraca pangan, penggunaan lahan sawah, pola perubahan penggunaan lahan

\section{PENDAHULUAN}

Beras merupakan makanan pokok bagi lebih dari setengah populasi dunia sehingga sangat penting untuk ketahanan pangan (Belesky, 2014; Cornish et al., 2015; Qiu et al., 2015; Yang and Zhang, 2014). Sebagian besar rakyat Indonesia juga masih sangat bergantung pada beras sebagai pangan pokoknya. Oleh karena itu, ketahanan pangan nasional selalu menjadi agenda penting dalam pembangunan nasional.
Pulau Jawa yang luasnya hanya 7\% dari luas daratan Indonesia saat ini menghasilkan 36.5 juta ton beras atau $52.89 \%$ dari produksi beras nasional (BPS, 2014). Hal ini menunjukkan ketergantungan pangan yang sangat tinggi terhadap pulau Jawa. Ketergantungan produksi beras pada Pulau Jawa tampaknya disebabkan oleh dua hal. Pertama, area sawah di Pulau Jawa lebih dominan dibandingkan pulau-pulau lainnya. Kedua, produktivitas lahan sawah di Jawa jauh lebih tinggi daripada sawah pulau-pulau lain (Widiatmaka et al., 2013). 
Sawah terdistribusi di wilayah bagian tengah sampai bagian utara kabupaten. Mendekati pantai utara (Laut Jawa), dominasi lahan sawah digantikan oleh tambak lahan basah. Luas penggunaan lahan sawah terus menurun dari tahun ketahun sepanjang analisis. Jika pada tahun 2000 luas lahan sawah adalah 116,268 ha atau $60.6 \%$ dari luas total Kabupaten Karawang, pada tahun 2013 luasnya menurun menjadi 103,866 ha $(54.14 \%)$. Bagian wilayah yang lahan sawahnya berkurang terutama adalah wilayahwilayah yang terletak di dekat perkotaan dan jalan raya, yaitu di wilayah bagian tengah Kabupaten Karawang.
Penggunaan lahan lain yang cukup luas adalah permukiman, yang menempati bagian perkotaan di bagian tengah sampai selatan wilayah kabupaten. Permukiman, dengan dominansi oleh lahan terbangun, mengalami peningkatan pada semua titik tahun analisis. Pada tahun 2000 luas lahan permukiman adalah 11,759 ha atau $6.13 \%$ dari total luas Kabupaten Karawang, pada tahun 2013 luasnya telah meningkat cukup besar menjadi 30,155 ha $(15.72 \%)$. Peningkatan terjadi terutama di bagian tengah wilayah kabupaten yang merupakan pusat kegiatan perkotaan dan industri.

Tabel 1. Luas dan persentase penggunaan dan tutupan lahan selama 2000-2013

\begin{tabular}{|c|c|c|c|c|c|c|c|c|c|c|}
\hline \multirow[t]{2}{*}{ Penggunaan lahan } & \multicolumn{2}{|c|}{2000} & \multicolumn{2}{|c|}{2003} & \multicolumn{2}{|c|}{2007} & \multicolumn{2}{|c|}{2010} & \multicolumn{2}{|c|}{2013} \\
\hline & Luas (ha) & $\%$ & Luas (ha) & $\%$ & Luas (ha) & $\%$ & Luas (ha) & $\%$ & Luas (ha) & $\%$ \\
\hline Hutan & 10,878 & 5.67 & 9,757 & 5.09 & 8,890 & 4.63 & 7,104 & 3.70 & 7,084 & 3.69 \\
\hline Perkebunan/kebun & 1,545 & 0.81 & 1,700 & 0.89 & 2,349 & 1.22 & 5,884 & 3.07 & 6,769 & 3.53 \\
\hline Permukiman & 11,759 & 6.13 & 15,431 & 8.04 & 20,330 & 10.60 & 24,121 & 12.57 & 30,155 & 15.72 \\
\hline Pertanian lahan kering & 23,654 & 12.33 & 19,546 & 10.19 & 24,135 & 12.58 & 17,697 & 9.22 & 15,484 & 8.07 \\
\hline Sawah & 116,268 & 60.60 & 115,908 & 60.41 & 112,017 & 58.38 & 108,532 & 56.57 & 103,866 & 54.14 \\
\hline Lahan tidak produktif & 9,328 & 4.86 & 9,999 & 5.21 & 4,466 & 2.33 & 8,800 & 4.59 & 8,473 & 4.42 \\
\hline Tambak & 17,454 & 9.10 & 18,545 & 9.67 & 18,699 & 9.75 & 18,748 & 9.77 & 19,055 & 9.93 \\
\hline Jumlah & 191,864 & 100.00 & 191,864 & 100 & 191,864 & 100 & 191,864 & 100 & 191,864 & 100 \\
\hline
\end{tabular}

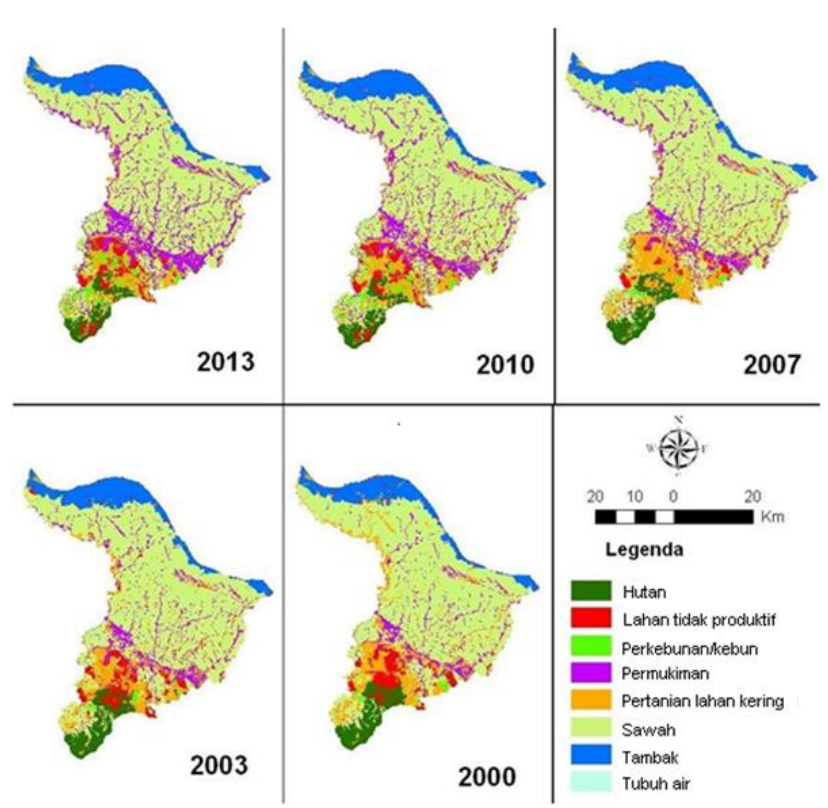

Gambar 2. Perubahan penggunaan lahan dan tutupan lahan lima titik tahun di Kabupaten Karawang yaitu 2000-2003; 2003-2007 dst

Tabel 2. Pola dominan perubahan penggunaan lahan

\begin{tabular}{|c|c|c|c|}
\hline \multirow{2}{*}{ No } & \multirow{2}{*}{ Pola perubahan penggunaan lahan } & \multicolumn{2}{|c|}{ Luas } \\
\hline & & ha & $\%$ \\
\hline 1. & $\begin{array}{l}\text { Sawah } \rightarrow \text { sawah } \rightarrow \text { permukiman } \rightarrow \\
\text { permukiman } \rightarrow \text { permukiman }\end{array}$ & $1,995.03$ & $1.04 \%$ \\
\hline 2. & $\begin{array}{l}\text { Pertanian lahan kering } \rightarrow \text { permukiman } \\
\rightarrow \text { permukiman } \rightarrow \text { permukiman } \rightarrow \\
\text { permukiman }\end{array}$ & $1,939.79$ & $1.01 \%$ \\
\hline 3. & $\begin{array}{l}\text { Pertanian lahan kering } \rightarrow \text { pertanian } \\
\text { lahan kering } \rightarrow \text { pertanian lahan kering }\end{array}$ & $1,917.95$ & $1.00 \%$ \\
\hline & $\begin{array}{l}\rightarrow \text { pertanian lahan kering } \rightarrow \\
\text { permukiman }\end{array}$ & & \\
\hline 4. & $\begin{array}{l}\text { Pertanian lahan kering } \rightarrow \text { pertanian } \\
\text { lahan kering } \rightarrow \text { pertanian lahan kering } \\
\rightarrow \text { lahan tidak produktif } \rightarrow \text { lahan tidak } \\
\text { produktif }\end{array}$ & $1,790.16$ & $0.93 \%$ \\
\hline 5. & $\begin{array}{l}\text { Sawah } \rightarrow \text { sawah } \rightarrow \text { sawah } \rightarrow \text { sawah } \\
\rightarrow \text { permukiman }\end{array}$ & $1,758.51$ & $0.92 \%$ \\
\hline
\end{tabular}

Hutan mengalami penurunan, namun tidak terlalu besar. Perkebunan atau kebun campuran dan tambak juga mengalami peningkatan, namun tidak terlalu luas peningkatannya. Sawah dan pertanian lahan kering mengalami penurunan yang cukup besar. Penggunaan lahan tubuh air tidak mengalami perubahan.

Pola dominan perubahan penggunaan lahan periode tahun 2000-2013 pada lima titik tahun, paling besar terjadi pada penggunaan lahan sawah menjadi permukiman yaitu seluas $1,995.03$ ha atau $1.04 \%$ dari luas total wilayah kabupaten. Pola ini menunjukkan bahwa perubahan penggunaan lahan sawah menjadi lahan non sawah sangat dominan di Kabupaten Karawang. Bertambahnya jumlah penduduk yang bekerja dan menetap di Kabupaten Karawang, terutama penambahan pekerja pada sektor industri membuat penggunaan lahan permukiman terus meningkat dari waktu ke waktu.

Pola dominan perubahan penggunaan lahan selanjutnya adalah penggunaan lahan pertanian lahan kering yang langsung berubah menjadi penggunaan lahan permukiman. Perubahan dengan pola ini adalah seluas $1,939.79$ ha $(1.01 \%)$. Hal ini menunjukkan bahwa dalam kurun 13 tahun ini, selain lahan sawah, penggunaan lahan pertanian lahan kering juga terkonversi menjadi permukiman. Pola dominan perubahan penggunaan lahan selanjutnya sama polanya yaitu penggunaan lahan kering menjadi permukiman, namun perubahannya terjadi secara bertahap antar titik tahun. Pola demikian luasnya adalah $1,917.95$ ha $(1.0 \%)$. Hal ini menunjukkan bahwa konversi lahan pertanian ke non-pertanian semakin tinggi terjadi pada tahun-tahun terakhir. Hal ini antara lain dipicu oleh semakin tingginya kebutuhan akan ruang untuk kegiatan manusia, dengan semakin bertambahnya penduduk.

Perlu dicatat pula adanya pola dominan penggunaan lahan dari penggunaan lahan pertanian lahan kering menjadi penggunaan lahan tidak produktif. Pola seperti ini terjadi di Kabupaten Karawang seluas 1,790.16 (0.93\%). Hal ini kemungkinan disebabkan karena lahan yang tidak produktif tersebut merupakan lahan yang dipersiapkan untuk permukiman dan saat analisis sengaja diterlantarkan. 
Pola dominan perubahan penggunaan lahan yang lain di wilayah ini adalah perubahan penggunaan lahan sawah yang bertahan dari tahun 2000 sampai 2010, kemudian terkonversi pada periode 2010-2013 menjadi permukiman. Pola ini memiliki luas sebesar 1,758 ha $(0.92 \%)$. Hal ini menunjukkan bahwa ada peningkatan konversi lahan sawah yang meningkat dalam tahun-tahun terakhir analisis. Dikhawatirkan, pada masa mendatang penurunan luas sawah akan semakin besar. Hal ini dapat membuat kontribusi Kabupaten Karawang dalam produksi beras akan semakin turun pada masa mendatang

Hasil-hasil analisis diatas menunjukkan bahwa pola perubahan penggunaan lahan akan stabil pada penggunaan lahan permukiman. Sebagai salah satu wilayah industri di Pulau Jawa dan juga penyangga Ibu kota negara, Kabupaten Karawang menjadi salah satu pusat lapangan pekerjaan sehingga menarik penduduk dari berbagai daerah untuk bermukim. Hal ini menjadi faktor pendorong meningkatnya pemukiman. Baik lahan sawah maupun pertanian lahan kering menjadi sasaran utama konversi.

\section{Neraca Pangan dan Kontribusi Kabupaten Karawang pada Produksi Beras}

Tabel 3 menyajikan perhitungan neraca pangan dan produksi beras dalam konteks kontribusi Kabupaten Karawang untuk memberikan surplus untuk daerah luar wilayahnya. Areal sawah yang disajikan pada Tabel 3 merupakan hasil interpretasi citra untuk tahun 2000, 2003, 2007, 2010, dan 2013. Data yang tercantum dalam tabel selama tahun-tahun lainnya (2001, 2002, 2004, 2005, 2006, 2008, 2009, 2011, dan 2012) adalah data ekstrapolasi menggunakan data hasil interpretasi citra tersebut. Perhitungan laju penurunan luas lahan sawah dalam kurun tahun 2001 sampai 2013 menghasilkan angka 954 ha per tahun atau konversi rata-rata $0.93 \%$ per tahun. faktor yang menyebabkan peningkatan produktivitas, antara lain penerapan teknologi (pupuk, insektisida, bibit unggul dan lain-lain), ditambah dengan kondisi perbaikan faktor sosial pertanian seperti bimbingan ke petani dan kelompok tani dan lain-lain (Widiatmaka et al., 2015). Nilai indeks pertanaman yang relatif konstan menunjukkan bahwa upaya perbaikan irigasi misalnya, belum banyak dilakukan.

Nilai produksi beras dalam tabel dihitung dari luas lahan sawah hasil interpretasi, nilainya dikonversi menjadi produksi kotor kemudian dikonversi juga dengan susut gabah menjadi produksi bersih pada perhitungan neraca pangan, kemudian dikonversi dengan gabah kering giling yang secara nasional nilainya sebesar $62.74 \%$. Lahan sawah dalam penelitian ini diasumsikan termasuk dalam sawah beririgasi teknis, sawah beririgasi semi teknis, sawah irigasi sederhana, dan sawah tadah hujan.

Sementara itu, data penduduk adalah data riil dari data statistik. Berdasarkan data tersebut, jumlah penduduk Kabupaten Karawang telah berkembang, dari 1,765,263 jiwa pada tahun 2000, menjadi 2,225,383 jiwa pada tahun 2013. Permintaan beras dihitung berdasarkan kebutuhan per-kapita. Kebutuhan beras per kapita diasumsikan sebesar $134 \mathrm{~kg}$ tahun $^{-1}$, yang terdiri dari konsumsi langsung rumah tangga $113 \mathrm{~kg}$ (BPS, 2001-2014) dan 21 $\mathrm{kg}$ merupakan kebutuhan industri pengolahan makanan (Balitbangtan, 2005).

Pada Gambar 3, dapat dinyatakan bahwa surplus produksi yang dapat disumbangkan Kabupaten Karawang keluar dari wilayahnya terus mengalami penurunan dalam periode 2000 hingga 2013. Jika pada tahun 2000 Kabupaten Karawang dapat memberikan kontribusi $56.51 \%$ dari produksi untuk dibagi dan diekspor keluar dari wilayahnya, maka pada tahun 2013, surplus yang bisa dibagi keluar dari wilayahnya menurun menjadi $52.35 \%$,

Tabel 3. Perhitungan surplus beras pada lahan sawah di Kabupaten Karawang

\begin{tabular}{|c|c|c|c|c|c|c|c|c|}
\hline Tahun & $\begin{array}{c}\text { Lahan sawah } \\
\text { (ha) }\end{array}$ & $\begin{array}{l}\text { Produktivitas } \\
\text { (ton/ha) }\end{array}$ & $\begin{array}{c}\text { Indeks } \\
\text { penanaman }^{4}\end{array}$ & $\begin{array}{c}\text { Produksi } \\
\text { beras }^{5} \\
\text { (ton) }\end{array}$ & $\begin{array}{c}\text { Jumlah } \\
\text { penduduk }^{4} \\
\text { (orang) }\end{array}$ & $\begin{array}{c}\text { Kebutuhan } \\
\text { beras }^{5} \\
\text { (ton) }\end{array}$ & $\begin{array}{l}\text { Surplus }^{5} \\
\text { (ton) }\end{array}$ & $\%$ Surplus ${ }^{5}$ \\
\hline 2000 & $116,268^{1}$ & 5.90 & 2.16 & $866,973.63$ & $1,765,263$ & $377,024.61$ & $489,949.02$ & 56.51 \\
\hline 2001 & $116,148^{3}$ & 5.97 & 2.20 & $892,583.13$ & $1,789,525$ & $382,206.49$ & $510,376.64$ & 57.18 \\
\hline 2002 & $116,028^{3}$ & 6.00 & 2.18 & $887,994.91$ & $1,837,930$ & $392,544.82$ & $495,450.09$ & 55.79 \\
\hline 2003 & $115,908^{1}$ & 6.05 & 2.14 & $878,056.55$ & 103,512 & $406,551.81$ & $471,504.73$ & 53.70 \\
\hline 2004 & $114,935^{3}$ & 6.34 & 2.22 & $946,532.22$ & $1,934,272$ & $413,121.53$ & $533,410.69$ & 56.35 \\
\hline 2005 & $113,963^{3}$ & 6.45 & 2.10 & $903,193.71$ & $1,971,463$ & $421,064.78$ & $482,128.93$ & 53.38 \\
\hline 2007 & $112,017^{1}$ & 6.20 & 2.33 & $946,828.83$ & $2,055,469$ & $439,006.77$ & $507,822.06$ & 53.63 \\
\hline 2008 & $110,855^{3}$ & 6.50 & 2.22 & $935,971.98$ & $2,094,408$ & $447,323.35$ & $488,648.63$ & 52.51 \\
\hline 2009 & $109,694^{3}$ & 7.03 & 2.15 & $970,097.23$ & $2,125,234$ & $453,907.17$ & $516,190.06$ & 53.21 \\
\hline 2010 & $108,532^{1}$ & 7.00 & 2.18 & $969,063.57$ & $2,127,791$ & $454,453.29$ & $514,610.28$ & 53.10 \\
\hline 2011 & $106,977^{3}$ & 7.01 & 2.20 & $965,316.40$ & $2,187,861$ & $467,283.03$ & $498,033.37$ & 51.59 \\
\hline 2012 & $105,421^{3}$ & 7.25 & 2.20 & $983,850.52$ & $2,207,181$ & $471,409.39$ & $512,441.12$ & 52.09 \\
\hline 2013 & $103,866^{2}$ & 7.46 & 2.20 & $997,412.58$ & $2,225,383$ & $475,296.97$ & $522,115.60$ & 52.35 \\
\hline
\end{tabular}

${ }^{1}$ Interpretasi citra landsat; ${ }^{2}$ Interpretasi citra landsat dengan pengecekan lapang; ${ }^{3}$ Nilai ekstrapolasi dari rata-rata konversi selama 10 tahun $(2003-2013) ;{ }^{4}$ Data statistik; ${ }^{5}$ Kalkulasi dari interpretasi citra dan data statistik.

Produktivitas dan indeks penanaman yang tercantum dalam tabel diambil dari data statistik Kabupaten Karawang dalam Angka (BPS, 2001-2014). Dari data statistik tersebut, dapat dinyatakan bahwa ratarata produktivitas lahan sawah di Kabupaten Karawang meningkat secara substansial, dari 5.90 ton ha ${ }^{-1}$ pada tahun 2000 menjadi 7.46 ton $\mathrm{ha}^{-1}$ pada tahun 2013. Ada banyak atau mengalami penurunan sebesar $5 \%$. Trend penurunan surplus produksi ini telah dinyatakan dalam penelitian sebelumnya sampai 2011 (Widiatmaka, 2013). 


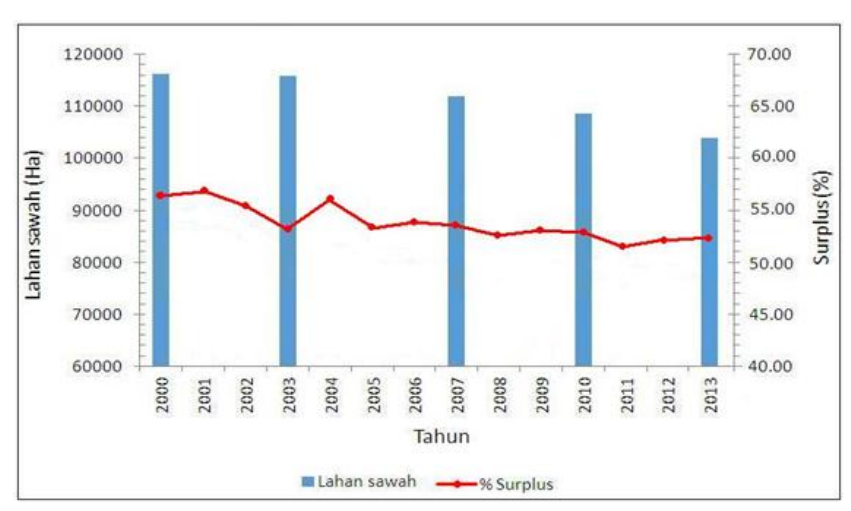

Gambar 3. Evolusi daerah sawah dan surplus produksi beras di Kabupaten Karawang selama tahun 2000-2013

Kontribusi penurunan ini relatif lebih kecil dibandingkan dengan penurunan luas lahan sawah, yang dalam 13 tahun terakhir mencapai $6.46 \%$. Hal ini antara lain disebabkan karena penurunan luas lahan diimbangi oleh peningkatan yang signifikan dari produktivitas. Namun demikian dalam jangka panjang, tetap mengkhawatirkan karena produktivitas padi yang saat ini 7.46 ton ha $^{-1}$ diperkirakan akan membutuhkan usaha lebih besar. Hal ini masih mungkin dilakukan, namun upaya keras perlu dilakukan melalui intensifikasi pertanian, yaitu dengan selalu mengembangkan penelitian dan pengembangan varietas baru, metode baru, pemupukan dan pengendalian hama. Cara lain yang perlu dilakukan adalah meningkatkan indeks pertanaman dengan meningkatkan kualitas irigasi, efisiensi penggunaan air dan meningkatkan upaya pemanfaatan benih unggul. Pada sisi lain, upaya mengurangi konsumsi beras perlu dilakukan secara kontinyu. Selain upaya-upaya tersebut, upaya yang sangat penting dilakukan adalah menghentikan penurunan secara kontinyu areal sawah baik dengan intensifikasi ataupun ekstensifikasi pertanian.

Jika fenomena penurunan luas lahan sawah seperti yang dijelaskan di Kabupaten Karawang terjadi di semua sentra produksi padi di Pulau Jawa, dikhawatirkan kedaulatan pangan nasional terancam. Dalam konteks ini, penerapan Undang-Undang Nomor 41 Tahun 2009 tentang Lahan Pertanian Pangan Berkelanjutan dan peraturan pelaksanaannya perlu dilaksanakan secara tuntas.

\section{SIMPULAN}

Dari penelitian ini, dapat disimpulkan bahwa dalam periode selama 2000 - 2013, ada perubahan penggunaan lahan dan tutupan lahan di Kabupaten Karawang, Indonesia, yang cukup intensif. Penggunaan lahan yang meningkat secara signifikan adalah pemukiman, baik yang berupa lahan terbangun untuk tempat tinggal ataupun untuk tempat bekerja. Pemukiman meningkat tiap hektarnya pada tahun 2000 ke tahun 2013. Penggunaan lahan dan tutupan lahan yang berkurang secara signifikan adalah sawah, dari 116,268 ha pada tahun 2000 menjadi 103,866 ha pada tahun 2013. Dalam hal pola perubahan penggunaan lahan dan tutupan lahan secara keseluruhan, dijelaskan bahwa sebagian besar permukiman luasnya meningkat berasal dari daerah sawah dan pertanian lahan kering yang dikonversi menjadi kawasan perumahan dan kawasan industri. Laju konversi lahan sawah di Karawang yaitu 954 ha per tahun atau $0.93 \%$ per tahun. Penurunan lahan sawah ini telah mengakibatkan pengurangan kontribusi Kabupaten Karawang untuk ketahanan pangan nasional. Penurunan ini mencapai 5\% selama 13 tahun terakhir.

Hal ini memerlukan upaya serius dari pemerintah, baik dalam konteks penurunan konversi sawah secara kontinyu, serta dalam konteks lebih mengoptimalkan kemampuan Kabupaten Karawang agar terus dapat berkontribusi untuk ketahanan pangan nasional.

Keadaan yang dijelaskan dalam makalah ini diperkirakan terjadi di hampir semua sentra produksi pangan di pulau Jawa. Penekanan pada perubahan penggunaan lahan dari lahan pertanian menjadi penggunaan lain untuk sektor lain pada masa depan akan meningkat. Untuk itu, upaya seperti menghentikan penurunan secara kontinyu areal sawah perlu dilakukan secara menyeluruh, untuk mengamankan ketahanan pangan nasional.

\section{DAFTAR PUSTAKA}

[Balitbangtan] Badan Penelitian dan Pengembangan Pertanian. 2005. Prospek dan Arah Pengembangan Agribisnis Padi. Balitbangtan, Jakarta.

Belesky, P. 2014. Regional governance, food security and rice reserves in East Asia. J. Global Food Security, 3: $167-173$.

[BKP Kementan] Badan Ketahanan Pangan Kementerian Pertanian. 2013. Pedoman Penyusunan Peta Ketahanan dan Kerentanan Pangan (Food Security and Vulnerability Atlas - FSVA) Nasional. BKP Kementan, Jakarta.

Borrelli, P., S. Modugno., P. Panagos., M. Marchetti., B. Schutt, and L. Montanarella. 2014. Detection of harvested forest areas in Italy using landsat imagery. J. Applied Geography, 48: 102-111.

[BPS] Badan Pusat Statistik Kabupten Karawang. 2001 2014. Kabupaten Karawang Dalam Angka Tahun 2000 - 2013. BPS, Karawang.

[BPS] Badan Pusat Statistik Kabupten Karawang. 2015. Kabupaten Karawang Dalam Angka Tahun 2014. BPS, Karawang.

[BPS] Badan Pusat Statistik Indonesia. 2014. Indonesia Dalam Angka Tahun 2013. BPS, Jakarta.

Cornish, P.S., D. Karmakar., A. Kumar., S. Das, and B. Croke. 2015. Improving crop production for food security and improved livelihoods on the East India Plateau. I. Rainfall-related risk with rice and opportunities for improved cropping systems. $J$. Agricult. Systems, 137: 166-179.

Kim, D.H., J.O. Sexton, P. Noojipady, C. Huang, A. Anand, S. Channan, M. Feng, and J.R. Townshend. 2014. Global, landsat-based forest-cover change 
from 1990 to 2000. J. Remote Sens. of Environment, 155:178-193.

Kolios, S. and C.D. Stylios. 2013. Identification of land cover/land use changes in the greater area of the Preveza peninsula in Greece using Landsat satellite data. J. Applied Geography, 40:150-160.

Qiu, B., W. Li, Z. Tang, C. Chen, and W. Qi. 2015. Mapping paddy rice areas based on vegetation phenology and surface moisture conditions. $J$. Ecological Indicators, 56:97-86.

Widiatmaka, W. Ambarwulan, and K. Munibah. 2013. Landuse change during a decade as determined by landsat imagery of a rice production region and its implication to regional contribution to rice self sufficiency: case study of Karawang Regency, West
Java, Indonesia. In G.H. Pramono, D. Ramdani, B. Barus and R.M. Ariansyah (Eds.). Proceedings of the 34th Asian Conference on Remote Sensing. The Festive Of Science, Education, Nation, And Culture. Masyarakat Ahli Penginderaan Jarak Jauh (MAPIN). Bali, Indonesia. p. 126-132.

Widiatmaka, K. Munibah, S.R.P. Sitorus, W. Ambarwulan, dan I. Firmansyah. 2015. Appraisal keberlanjutan multi-dimensi penggunaan lahan untuk sawah di Karawang, Jawa Barat. Jurnal Kawistara, 5: 113-131.

Yang, D. and M. Zhang. 2014. Effects of land-use conversion from paddy field to orchard farm on soil microbial genetic diversity and community structure. European J. of Soil Biology, 64:30-39. 